University of Nebraska - Lincoln

DigitalCommons@University of Nebraska - Lincoln

3-10-2021

\title{
Conservation management improves agroecosystem function and resilience of soil nitrogen cycling in response to seasonal changes in climate
}

\author{
Lidong Li \\ University of Tennessee, Knoxville \\ Julie Konkel \\ University of Tennessee, Knoxville \\ Virginia L. Jin \\ Agroecosystem Management Research Unit \\ Sean M. Schaeffer \\ University of Tennessee, Knoxville
}

Follow this and additional works at: https://digitalcommons.unl.edu/usdaarsfacpub

Part of the Agriculture Commons

Li, Lidong; Konkel, Julie; Jin, Virginia L.; and Schaeffer, Sean M., "Conservation management improves agroecosystem function and resilience of soil nitrogen cycling in response to seasonal changes in climate" (2021). Publications from USDA-ARS / UNL Faculty. 2521.

https://digitalcommons.unl.edu/usdaarsfacpub/2521

This Article is brought to you for free and open access by the U.S. Department of Agriculture: Agricultural Research Service, Lincoln, Nebraska at DigitalCommons@University of Nebraska - Lincoln. It has been accepted for inclusion in Publications from USDA-ARS / UNL Faculty by an authorized administrator of DigitalCommons@University of Nebraska - Lincoln. 


\title{
Conservation management improves agroecosystem function and resilience of soil nitrogen cycling in response to seasonal changes in climate
}

\author{
Lidong Li $^{\text {a,b,* }}$, Julie Konkel ${ }^{\mathrm{a}, \mathrm{c}}$, Virginia L. Jin ${ }^{\mathrm{b}}$, Sean M. Schaeffer ${ }^{\mathrm{a}, * *}$ \\ a University of Tennessee-Knoxville, Department of Biosystems Engineering and Soil Science, 2506 E. J. Chapman Drive, Knoxville, TN 37996, USA \\ b USDA-ARS, Agroecosystem Management Research Unit, 251 Filley Hall, UNL-East Campus, Lincoln, NE 68583, USA \\ c Blount County Soil Conservation District, 1217 McArthur Rd, Maryville, TN 37804, USA
}

\section{H I G H L I G H T S}

- Inorganic nitrogen fertilizer and vetch cover crop accelerate microbial nitrogen transformation.

- Increased temperature and intensified precipitation destabilize soil nitrogen.

- Soil nitrogen is less sensitive to climate change with inorganic nitrogen fertilizer, vetch cover crop, and no-till.

- Vetch cover crop has a larger effect than inorganic nitrogen fertilizer on mitigating climatic effect on soil nitrogen.

\section{A R T I C L E I N F O}

\section{Article history:}

Received 29 September 2020

Received in revised form 9 March 2021

Accepted 10 March 2021

Available online 15 March 2021

Editor: Charlotte Poschenrieder

\section{Keywords:}

Increased temperature

Intensified precipitation

Soil microbial biomass nitrogen

Soil nitrate

\section{G R A P H I C A L A B S T R A C T}

Structural equation model for seasonal changes of soil $\mathrm{N}$ concentrations driven by climatic factors. Temperature: 30-day average air temperature prior to sampling day; Precipitation: 30-day cumulative precipitation prior to sampling day; MBN: microbial biomass N; EON: extractable organic N. Boxes indicate variables. Arrows represent causal relationships. All presented relationships are significant at $p \leq 0.05$. Arrow direction indicates the direction of causation. Arrow width indicates effect size. Black arrows denote positive relationships, and gray arrows negative relationships. Numbers beside arrows are standardized path coefficients, i.e., effect sizes.

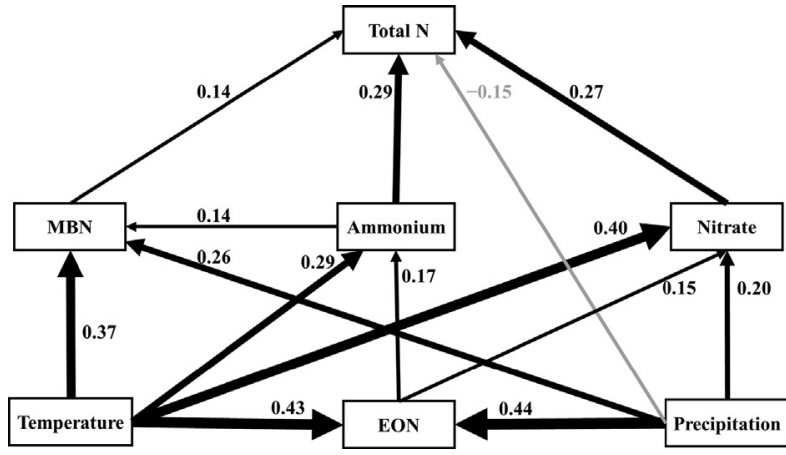

\begin{abstract}
A B S T R A C T
Understanding how conservation agricultural management improves soil nitrogen (N) stability in the face of climate change can help increase agroecosystem productivity and mitigate runoff, leaching and downstream water quality issues. We conducted a 2 -year field study in a 36-year-old rain-fed cotton production system to evaluate the impacts of changing climatic factors (temperature and precipitation) on soil $\mathrm{N}$ under conservation management, including moderate inorganic $\mathrm{N}$ fertilizer application $\left(0\right.$ and $\left.67 \mathrm{~kg} \mathrm{~N} \mathrm{ha}^{-1}\right)$, winter cover crops (fallow; winter wheat, Triticum aestivum L.; hairy vetch, Vicia villosa Roth), and reduced tillage (no-till; disk tillage). Structural equation modeling (SEM) was used to quantify and compare the effects of conservation management and climatic factors on soil $\mathrm{N}$ concentrations. Fertilizer and vetch cover crops increased soil total $\mathrm{N}$ concentration by $16 \%$ and $18 \%$, respectively, and also increased microbial $N$ transformation rate by $41 \%$ and $168 \%$. In addition, vetch cover crops also increased soil labile $\mathrm{N}$ concentrations by $57 \%, 21 \%$, and $79 \%$, i.e., extractable organic $\mathrm{N}$, ammonium, and nitrate, respectively. The highest soil $\delta^{15} \mathrm{~N}$ value $\left(6.4 \pm 0.3 \%\right.$ ) was observed under the $67 \mathrm{~kg} \mathrm{~N}^{-1}$ fertilizer-wheat-disk tillage treatment, and the lowest value ( $4.8 \pm 0.3 \%$ ) under the zero-fertilizer-wheat-notill treatment, indicating fertilizer and tillage might accelerate microbial $\mathrm{N}$ transformation. The SEM showed
\end{abstract}

\footnotetext{
* Correspondence to: L. Li, USDA-ARS, Agroecosystem Management Research Unit, 251 Filley Hall, UNL-East Campus, Lincoln, NE 68583, USA.

** Corresponding author.

E-mail addresses: 1li59@vols.utk.edu (L. Li), sschaef5@utk.edu (S.M. Schaeffer).
} 
Soil nitrogen mineralization Soil $\delta^{15} \mathrm{~N}$ positive effects of temperature and precipitation on labile $\mathrm{N}$ concentrations, suggesting destabilization of soil $\mathrm{N}$ and the potential for soil $\mathrm{N}$ loss under increased temperature and intensified precipitation. Fertilizer and vetch use might mitigate some of the effects of temperature by accelerating microbial $\mathrm{N}$ transformations, with vetch having a larger effect than fertilizer ( 0.35 vs. 0.15 , Table 1$)$. No-till can reduce some of the effects of precipitation on soil labile $\mathrm{N}$ by maintaining soil structure. Our study suggests that fertilizer, vetch cover crop, and no-till might help improve function and resilience of agroecosystems in relation to soil $\mathrm{N}$ cycling. Soil $\mathrm{N}$ stabilization in cropping systems can be enhanced by adjusting agricultural management.

(C) 2021 Elsevier B.V. All rights reserved.

\section{Introduction}

The key processes in terrestrial and aquatic ecosystems related to nitrogen $(\mathrm{N})$ cycling and availability are altered by climate change (Greaver et al., 2016). Seasonal changes in temperature and precipitation can exacerbate soil $\mathrm{N}$ loss from agroecosystems, but conservation agricultural management can help mitigate the soil $\mathrm{N}$ loss (Congreves et al., 2016) and therefore reduce $\mathrm{N}$ enrichment in aquatic ecosystems. Agricultural management such as inorganic $\mathrm{N}$ fertilizer application, cover crop use, and tillage can affect microbial cycling of soil $\mathrm{N}$ and therefore soil $\mathrm{N}$ availability. Applying inorganic $\mathrm{N}$ fertilizer can decrease microbial biomass by $5-15 \%$ on a global scale (Lu et al., 2011; Treseder, 2008) and alter soil microbial diversity (Mei et al., 2018; Šimek et al., 1999) and community structure (Kumar et al., 2018). Inorganic N fertilizer, however, also can increase microbial activities such as respiration and decomposition (Comeau et al., 2016; Fang et al., 2017; Graham et al., 2014), soil N mineralization (Risch et al., 2020), and denitrification (Ozlu and Kumar, 2018). Soil N losses due to long-term or overapplication of fertilizer, however, can result in significant nutrient inputs into water bodies and lead to pervasive water pollution (Yu et al., 2019), with toxic algal blooms, deficiency in dissolved oxygen, and reduction in fish production along the freshwater-to-marine continuum (Wurtsbaugh et al., 2019). To decrease agroecosystem $\mathrm{N}$ losses due to over-application of inorganic $\mathrm{N}$ fertilizer, leguminous cover crops or cover crop mixes that include $\mathrm{N}$-fixing species have potential to partially or fully replace inorganic $\mathrm{N}$ fertilizers.

The use of winter cover crops can further help reduce agroecosystem $\mathrm{N}$ losses by preventing leaching and/or runoff in the off-season by scavenging excess fertilizer N (Abdalla et al., 2019; Wang et al., 2018). Winter cover crops can transform residual inorganic $\mathrm{N}$ from synthetic fertilizers into organic $\mathrm{N}$ forms. Further, the presence of cover crop biomass acts as a physical barrier on top of the soil, reducing raindrop impact during what would otherwise be a bare fallow period (Chatterjee and Clay, 2016). The subsequent decomposition of the cover crop residues can also increase soil $\mathrm{N}$ availability for the succeeding primary crops and increase yields (Nouri et al., 2020; Vogeler et al., 2019). Cover crop choice, however, has a significant impact on whether nutrients are retained or lost from agricultural soils. Compared to nonlegume cover crops, $\mathrm{N}$-fixation by leguminous cover crops can result in significantly higher $\mathrm{N}$ leaching losses (Sievers and Cook, 2018) and higher soil nitrous oxide $\left(\mathrm{N}_{2} \mathrm{O}\right)$ emissions to the atmosphere (Shelton et al., 2018).

Additionally, the physical disruption of soil using tillage practices can decrease soil total and available N (Martínez et al., 2017; Mazzoncini et al., 2016) and affect nitrate leaching by altering soil structure and water movement. For example, increasing tillage frequency can decrease soil nitrate concentrations because of greater nitrate leaching through more water diffusion paths (Matthews et al., 2000; Xiao et al., 2019). In contrast, no-till systems may have higher bulk density and penetration resistance than tilled systems (Mbuthia et al., 2015; Nouri et al., 2019; Villamil et al., 2015), thereby decreasing nitrate leaching losses. However, the higher bulk density in no-till systems may increase the percent of water-filled pore space and therefore lead to greater denitrification potential compared with tilled systems (Pareja-Sánchez et al., 2020; Wang and Zou, 2020).
In this study, we compared the side-by-side impacts of long-term conservation agricultural management (moderate inorganic $\mathrm{N}$ fertilization, winter cover cropping, no-till) on soil $\mathrm{N}$ dynamics under changing climatic factors (temperature, precipitation). Further, we examined effects of conservation management and climatic factors on soil $\mathrm{N}$ concentrations over different times in the growing season for two years. Specifically, we hypothesized that: (1) inorganic N fertilizer, vetch cover crop, and no-till would increase soil total N concentration; (2) increased temperature and/or intensified precipitation would increase soil labile N concentrations; (3) soil labile N concentrations would be less sensitive to temperature and precipitation under inorganic $\mathrm{N}$ fertilizer, vetch cover crop, and no-till. To test these hypotheses, we measured soil total $\mathrm{N}$ and $\delta^{15} \mathrm{~N}$ values, labile $\mathrm{N}$ concentrations (extractable organic $\mathrm{N}$, ammonium, and nitrate), microbial biomass $\mathrm{N}$, and potential $\mathrm{N}$ mineralization rate at eight times over the 2016 and 2017 crop years. We then applied these data to structural equation modeling to evaluate the effects of conservation management and climatic factors on soil $\mathrm{N}$ concentrations.

\section{Materials and methods}

\subsection{Site selection, experiment design, and soil sampling}

Soil was collected from the West Tennessee Research and Education Center located in Jackson, Tennessee, USA ( $35^{\circ} 37^{\prime} 23.1^{\prime \prime} \mathrm{N} 88^{\circ} 50^{\prime} 47.4^{\prime \prime}$ $\mathrm{W})$. The soil is classified as Lexington silt loam (fine-silty, mixed, thermic, Ultic Hapludalf) with slopes of $0-2 \%$. The site has been maintained as continuous cotton (Gossypium hirsutum L.) since 1981. The long-term conservation management practices in the field involve reduced inorganic $\mathrm{N}$ fertilization, winter cover cropping, and no-till. More detailed information of the field experiment and management are available in a previous study (Nouri et al., 2020).

A subset of treatment combinations in the field were evaluated in this study. Our experiment is a randomized complete block design with split-split-split-split plots. Each combination of treatments had four replicates. The inorganic $\mathrm{N}$ fertilizer (ammonium nitrate) treatment on the whole plot had two levels: 0 and $67 \mathrm{~kg} \mathrm{~N} \mathrm{ha}^{-1}$. The cover crop treatment on the split plot had three levels: bare fallow, winter wheat (Triticum aestivum L.), and hairy vetch (Vicia villosa Roth). The tillage treatment on the split-split plot had two levels: no-till and disk tillage. The disk tillage is usually performed two times before cotton planting: first, by a standard disk harrow and second, by smoothing and breaking up of clods by a harrow. Sampling year on the split-splitsplit plot, as a treatment, had two levels: 2016 and 2017. Sampling month on the split-split-split-split plot had four levels, where soils were sampled four times per year during growing season. The four sampling times were chosen to represent key management operations or crop developmental stages in this cotton production system. The first sampling was conducted as close to peak growth of cover crops as possible, usually one week before or within two weeks after cover crop harvest in March or April. The second collection was taken when cotton was well established, about four to six weeks after cover crop termination and after cotton planting, but before inorganic fertilizer application in May. The third sampling occurred as close to cotton peak growth as possible, within one to three weeks prior to cotton harvest in October. 
The fourth sampling occurred after harvest and before ground freezing, within two weeks following cotton harvest in November. Soil samplings were conducted on March 10, May 31, October 2, and November 14 in 2016, and April 10, May 22, October 2, and November 14 in 2017.

At each sampling time, soil cores were collected by an auger to a depth of $7.5 \mathrm{~cm}$. Seven to ten soil cores were taken from various locations within each plot, composited, and passed through a $2 \mathrm{~mm}$ mesh sieve to homogenize. The sieved soil was placed in a Ziplock bag for transport to the laboratory. Between each plot, sampling tools were cleaned with $70 \%$ ethanol. Fresh soils were stored at $4{ }^{\circ} \mathrm{C}$ until laboratory analyses. Soils for incubations (see below) were collected the same way.

\subsection{Bulk soil total $\mathrm{N}, \delta^{15} \mathrm{~N}$ value, and soil $\mathrm{pH}$}

A subsample of $2 \mathrm{~mm}$-sieved fresh soil was oven dried at $65{ }^{\circ} \mathrm{C}$, ground to powder, and analyzed for total $\mathrm{N}$ and $\delta^{15} \mathrm{~N}$ value using dry combustion (Stable Isotope Facility; University of California-Davis). A separate subsample of fresh soil was added to sterile water (1:2 extraction ratio), vortexed, and allowed to settle before measuring for $\mathrm{pH}$ (Ultrabasic, Denver Instrument, Bohemia, NY, USA).

\subsection{Soil extracts}

Soil total extractable $\mathrm{N}$ and microbial biomass $\mathrm{N}$ were measured by a chloroform slurry method (Fierer and Schimel, 2002). For each field sample, one soil subsample was chloroform-exposed and another subsample non-chloroform-exposed, and then both were extracted with $0.5 \mathrm{M} \mathrm{K}_{2} \mathrm{SO}_{4}$. Filtered extracts were kept under $-20{ }^{\circ} \mathrm{C}$ until analyses (see Section 2.5).

\subsection{Incubation for soil potential $N$ mineralization}

Fresh soils were incubated in mason jars under $25^{\circ} \mathrm{C}$ for 7 days. The incubated soils were extracted as described in Section 2.3. These soil extracts were used for the following extract analyses in Section 2.5 to de-

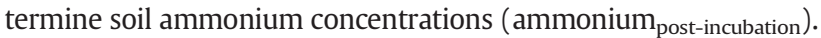

\subsection{Soil extract analyses}

Soil extracts obtained from Section 2.3 were analyzed for soil total extractable $\mathrm{N}$ (TEN) concentrations $\left(\mathrm{TEN}_{\mathrm{chloroform}-\text { exposed }}\right.$ and $\mathrm{TEN}_{\text {non-chloroform-exposed }}$ ) on a total organic carbon analyzer (Aurora 1030 W, OI Analytical, College Station, Taxes, USA) modified with a $\mathrm{N}$ detection for combustion analysis. Non-chloroform-exposed soil extracts from Section 2.3 were analyzed for ammonium pre-incubation $_{\text {and }}$ nitrate concentrations using microplate-based spectrophotometric determinations (Doane and Horwáth, 2003; Rhine et al., 1998). Extracts from Section 2.4 were also analyzed for ammonium post-incubation $_{\text {using }}$ microplate-based methods. Briefly, soil extracts were pipetted into 96-well plates. Reagents were added to each well. After reactions complete, the plate was read on a microplate reader (Synergy HT, BioTek, Winooski, VT, USA).

\subsection{Soil $N$ concentration and cycling rate calculations}

Soil total $\mathrm{N}$ was evaluated as concentration ( $\mathrm{mg} \mathrm{N} \mathrm{g}^{-1}$ dry soil). Soil microbial biomass $\mathrm{N}$ (MBN, $\mu \mathrm{g} \mathrm{N} \mathrm{g}{ }^{-1}$ dry soil) concentration was calculated as $\mathrm{MBN}=\mathrm{TEN}_{\text {chloroform-exposed }}-\mathrm{TEN}_{\text {non-chloroform-exposed. }}$ The MBN was not corrected for fumigation coefficient and thus represent a 'flush' of N instead of the total microbial biomass (Fierer et al., 2003). Soil extractable organic $\mathrm{N}$ (EON, $\mu \mathrm{g} \mathrm{N} \mathrm{g} \mathrm{g}^{-1}$ dry soil) concentration was calculated as EON $=$ TEN - ammonium $_{\text {pre-incubation }}-$ nitrate. Potential $\mathrm{N}$ mineralization (PNM, $\mu \mathrm{g} \mathrm{N}^{-1}$ dry soil $\mathrm{d}^{-1}$ ) rate was calculated as $\mathrm{PNM}=\left(\right.$ ammonium $_{\text {post-incubation }}-$ ammonium $\left._{\text {pre-incubation }}\right) / 7$ day.

\subsection{Statistical analyses}

A five-way mixed model ANOVA was used to determine the main and interaction effects of inorganic $\mathrm{N}$ fertilizer, cover crop, tillage, sampling year, and sampling month on soil $\mathrm{N}$ concentrations (Glimmix procedure; SAS 9.4, SAS Institute Inc., Cary, NC, USA). Inorganic N fertilizer rate, cover crop type, tillage type, sampling year, and sampling month were the fixed factors, and block was the random factor. The Univariate procedure was used for checking normality of residuals. Normality was determined by the Shapiro-Wilk's test at $p \leq 0.05$. Equal variance was determined by the Levene's test at $p \leq 0.05$. Post-hoc least squares means for treatments were compared by Fisher's Least Significant Difference (LSD), with Tukey-adjusted $p$-values. Significance was set at $p \leq 0.05$, and results were reported as mean \pm standard error.

The effect sizes of conservation management and climatic factors on soil $\mathrm{N}$ concentrations were quantified with structural equation modeling (AMOS 26; IBM Corporation, Meadville, PA, USA). We followed the procedures of developing and modifying a structural equation model in Byrne (2013) and Li et al. (2019a). Briefly, we proposed the a priori model according to experience and background information, tested if important pathways were left out (modification indices $\geq 4$ ) and if the existing pathways were significant $(p \leq 0.05)$, and then revised the $a$ priori model by adding missing pathways and dropping insignificant pathways in consideration of model fit and scientific rationality. Multivariate normality was assessed by Kurtosis values $\leq 7$. Path coefficients were tested by maximum likelihood estimation. Standardized path coefficients were reported as effect sizes based on standard deviation units, ranging from 0 to 1 . Model fit was evaluated by (1) the minimum discrepancy divided by its degrees of freedom (CMIN/DF) in the range of 1 to 3 (Carmines and Mclver, 1983), (2) the goodness of fit index (GFI) close to 1 (Tanaka and Huba, 1985), (3) the comparative fit index (CFI) close to 1 (Bentler, 1990), and (4) the root mean square error of approximation (RMSEA) less than 0.05 (Browne and Cudeck, 1993).

\section{Results}

\subsection{Soil total $N$ concentration, $\delta^{15} N$ value, and soil $p H$}

Soil total $N$ differed for the main effects of fertilizer $(p=0.0197)$ and cover crop $(p<0.0001)$, and the 3-way effect of tillage, year, and month $(p=0.0042$, Fig. 1$)$. There were no other significant interaction effects involving fertilizer or cover crop treatments. Soil total $\mathrm{N}$ concentration under $67 \mathrm{~kg} \mathrm{~N} \mathrm{ha}^{-1}$ fertilizer was 16\% higher than zero-fertilizer, and $18 \%$ higher under vetch cover crop compared to fallow. Soil total N concentration was the numerically lowest in the zero-fertilizer-wheat-disk treatment $\left(0.85 \pm 0.02 \mathrm{mg} \mathrm{Ng}^{-1}\right.$ soil $)$, and the highest in the $67 \mathrm{~kg} \mathrm{Nha}^{-1}$ fertilizer-vetch-no-till treatment $\left(1.72 \pm 0.06 \mathrm{mg} \mathrm{N} \mathrm{g}^{-1}\right.$ soil, Supplementary Fig. 1). There was no difference in total $\mathrm{N}$ concentration between wheat cover crop soils and fallow soils $(p=0.9936)$. Soil total $\mathrm{N}$ concentration under no-till was $\sim 8 \%$ higher than disk tillage, but only in October 2016, November 2016, and October 2017 ( $p<0.0069, p=$ 0.0275 , and $p<0.0001$, respectively, Fig. 1). In both 2016 and 2017, soil total $\mathrm{N}$ concentration in March was the lowest, increasing gradually in May, peaking in October, then decreasing in November (Supplementary Fig. 1).

Soil $\delta{ }^{15} \mathrm{~N}$ value was affected by the main effect of tillage $(p=0.0054)$ and the 2 -way effect of year and month $(p<0.0001)$. There were no significant interaction effects involving fertilizer, cover crop, or tillage treatments. Soil $\delta^{15} \mathrm{~N}$ value under disk tillage was higher than no-till. The highest value $\left(6.4 \pm 0.3 \%\right.$ ) was observed under the $67 \mathrm{~kg} \mathrm{~N} \mathrm{ha}^{-1}$ fertilizer-wheat-disk tillage treatment, and the lowest value $(4.8 \pm$ $0.3 \%$ ) under the zero-fertilizer-wheat-no-till treatment (Supplementary Fig. 2). Soil $\delta^{15} \mathrm{~N}$ value did not change significantly in 2016, decreased in April 2017, and increased in November 2017 to the same level as in 2016. 

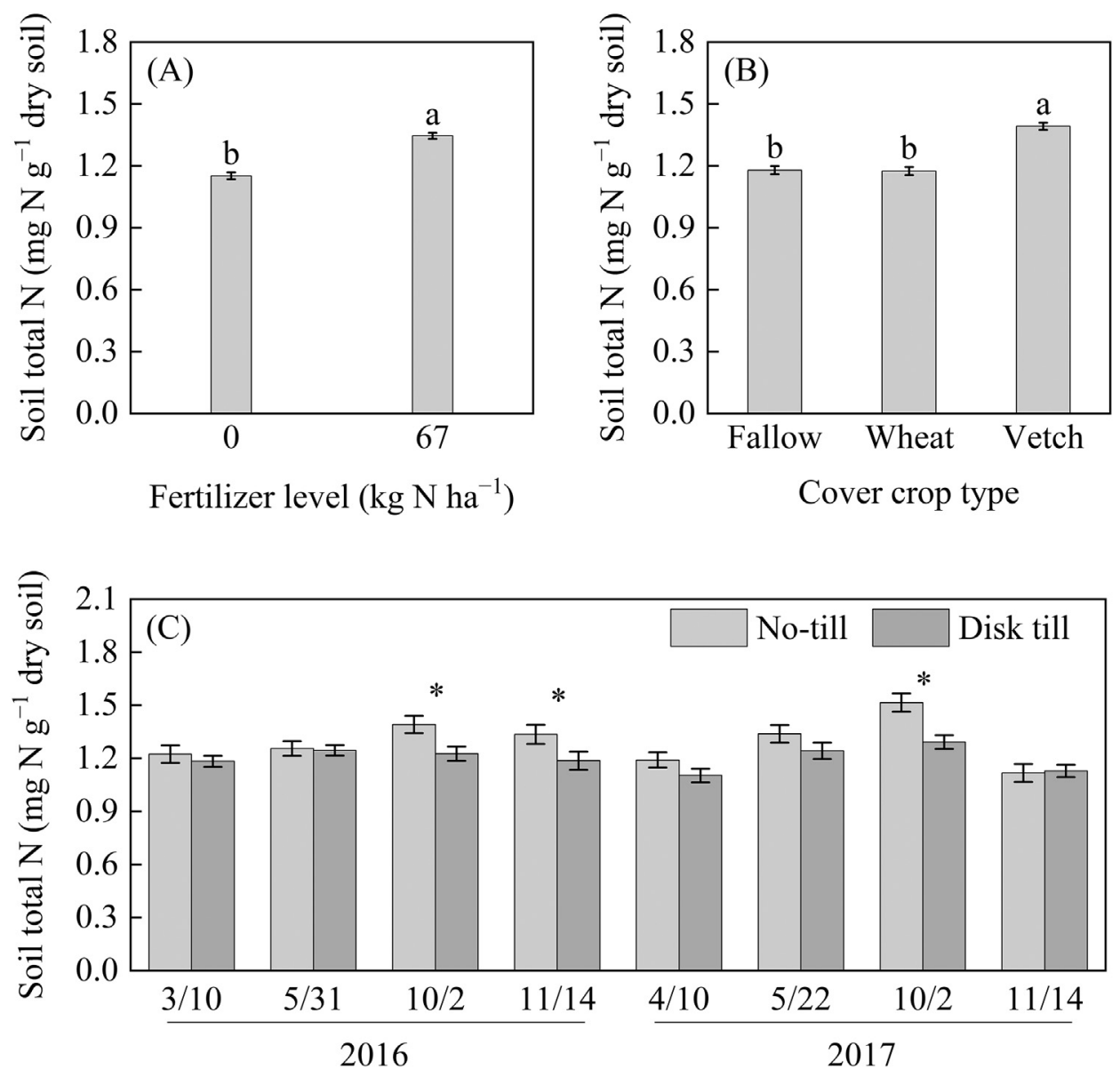

Sampling date

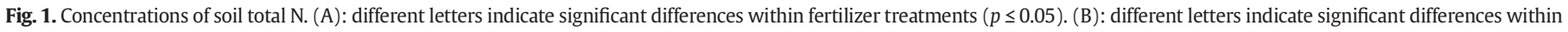
cover crop treatments. (C): an asterisk denotes a significant difference within tillage treatments.

Soil $\mathrm{pH}$ ranged from $5.32 \pm 0.10$ to $6.71 \pm 0.11$ (Supplementary Fig. 3 ) and varied for the main effect of tillage $(p=0.0308)$, the 3 -way effect of fertilizer, cover crop, and year $(p=0.0150)$, and the 2 -way effect of year and month $(p<0.0001)$. There were no other significant interaction effects involving tillage treatment. Soil $\mathrm{pH}$ was greater under disk tillage compared to no-till. Soil pH was lower under vetch than wheat cover crops only under the zero-fertilizer treatment in 2017 ( $p=0.0175$ ), and lower in 2017 than 2016 only under the zero-fertilizer-vetch treatments $(p<0.0001)$. In 2016, soil pH in March was lower than that in May but higher than that in November; in 2017, soil $\mathrm{pH}$ was lower than that in October and November $(p<0.0001)$.

\subsection{Microbial and extractable soil $N$ concentrations}

Soil microbial biomass $\mathrm{N}$ concentration (MBN) was affected by the 4 -way interactions of fertilizer, tillage, year, and month $(p=0.0489)$ and the 3-way interactions of cover crop, tillage, and year ( $p=$ 0.0253 , Fig. 2). In May 2016 only, MBN was lower under $67 \mathrm{~kg} \mathrm{~N} \mathrm{ha}^{-1}$ fertilizer compared to zero-fertilizer but only when soil was disked $(p=0.0280)$, and higher in disked than no-till soils but only when no fertilizer was applied $(p=0.0024)$. Soil MBN was lower in 2017 than 2016 but only under the fallow-disk treatment $(p=0.0382$ ).

Soil extractable organic $\mathrm{N}$ concentration (EON) was affected by the 3 -way effects of cover crops, year, and month ( $p=0.0010$, Fig. 3 ). Soil EON was higher under vetch cover crops compared to fallow and wheat cover crops but only in May $2017(p<0.0001)$. There were no main or interaction effects of tillage or fertilizer on EON.
Three different 3-way treatment interactions affected soil ammonium concentrations: ( 1$)$ fertilizer, cover crop, and tillage $(p=$ $0.0079)$; (2) cover crop, year, and month $(p<0.0001)$; and (3) tillage, year, and month ( $p=0.0035$, Fig. 4). Soil ammonium concentration was higher under the $67 \mathrm{~kg} \mathrm{~N} \mathrm{ha}^{-1}$ fertilizer-vetch-no-till treatment $\left(1.90 \pm 0.19 \mu \mathrm{g} \mathrm{N} \mathrm{g}^{-1}\right.$ soil $)$ compared to the other treatments $\left(1.15 \pm 0.09\right.$ to $1.46 \pm 0.15 \mu \mathrm{g} \mathrm{N} \mathrm{g}^{-1}$ soil). Soil ammonium concentration was higher under vetch cover crops than fallow but only in April 2017 ( $p<0.0001)$, and higher in no-till than disked soils in October 2017 only $(p<0.0001)$.

Soil nitrate concentration was affected by the 2-way effect of fertilizer and month ( $p=0.0249)$, and the 4 -way effect of cover crop, tillage, year, and month ( $p=0.0326$, Fig. 5$)$. With the $67 \mathrm{~kg} \mathrm{~N}^{-1}$ fertilizer application, monthly fluctuations of soil nitrate concentration were different from each other; without the inorganic $\mathrm{N}$ fertilizer, soil nitrate concentration at the first and the third sampling was not different from each other. Vetch cover crops increased soil nitrate concentration compared to fallow under no-tilled soils in May 2016, November 2016, and May 2017 and under tilled soils in May $2017(p<0.0001)$.

\subsection{Potential $N$ mineralization rate}

Potential $\mathrm{N}$ mineralization rate (PNM) was affected by the main effect of fertilizer ( $p=0.0040)$, the 2 -way effect of cover crops and tillage $(p=0.0310)$, and the 3-way effect of tillage, year, and month $(p=$ 0.0299, Fig. 6). The $67 \mathrm{~kg} \mathrm{~N} \mathrm{ha}^{-1}$ fertilizer treatment increased PNM 


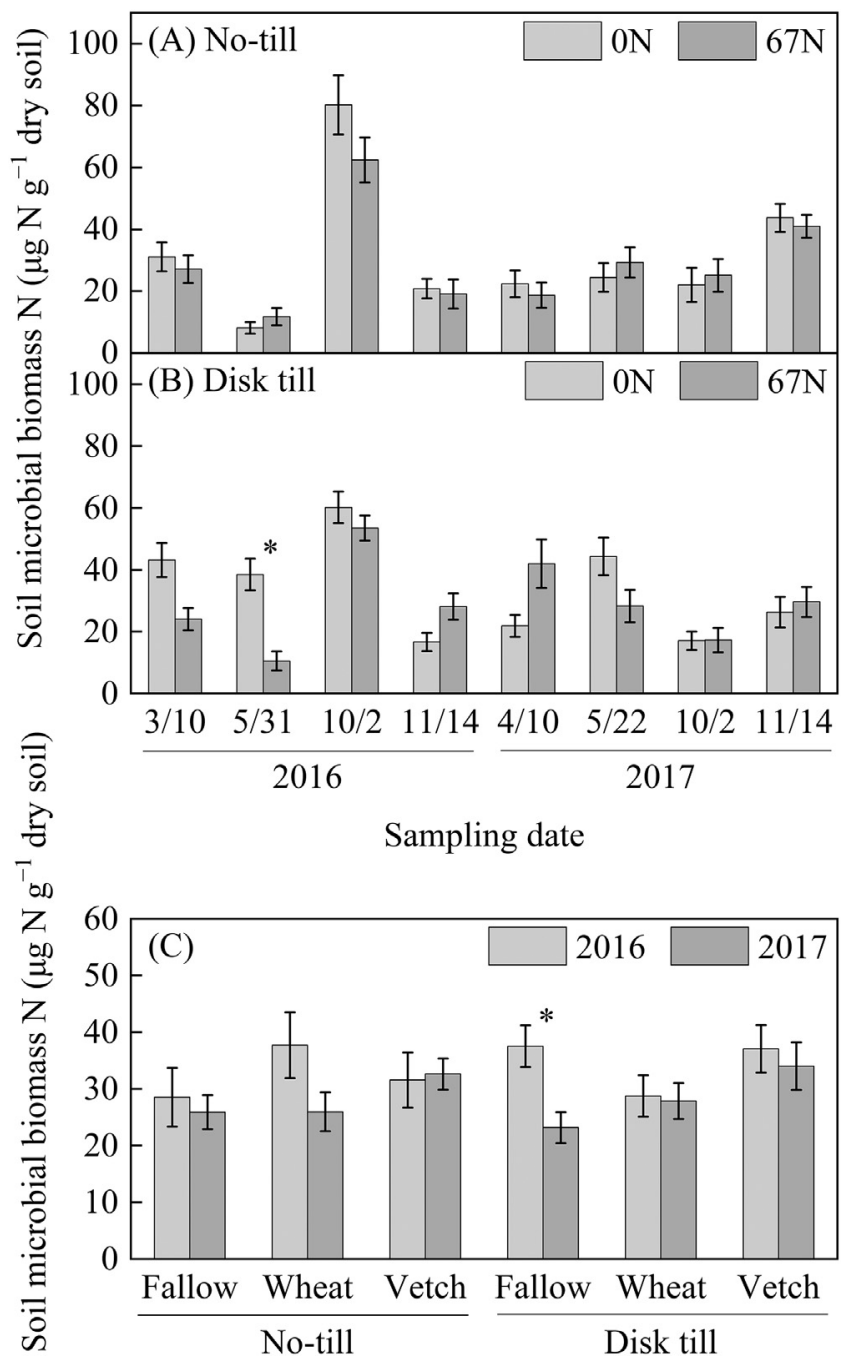

Fig. 2. Concentrations of soil microbial biomass N. (A) and (B): an asterisk denotes a significant difference within fertilizer treatments $(p \leq 0.05)$. (C): an asterisk denotes a significant difference within sampling years.

by up to 4 times compared to the zero-fertilizer treatment $(0.35 \pm 0.03$ vs. $0.25 \pm 0.03 \mu \mathrm{g} \mathrm{N} \mathrm{g}^{-1}$ soil $\left.\mathrm{d}^{-1}\right)$. Soil PNM was higher under vetch cover crops compared to fallow and wheat cover crops in both disked

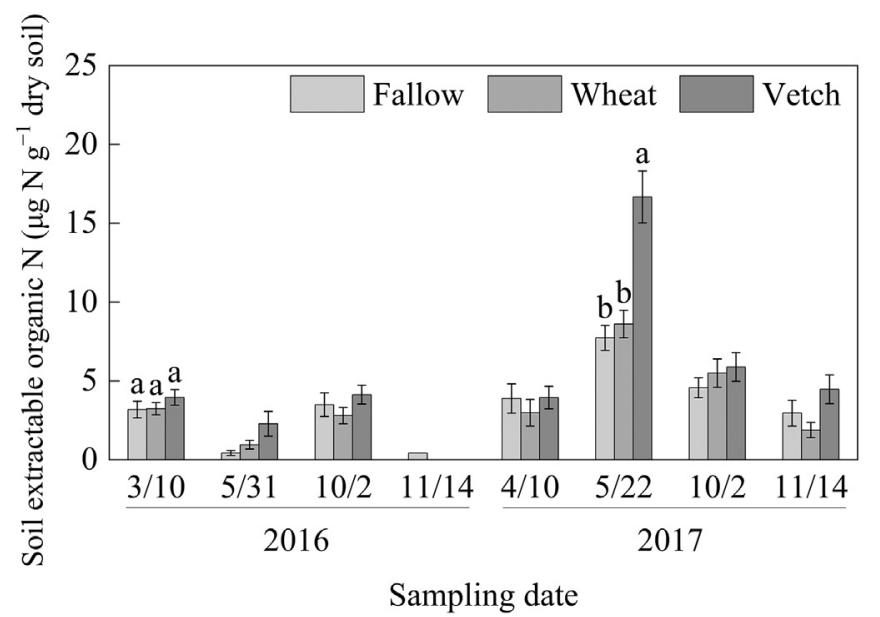

Fig. 3. Concentrations of soil extractable organic N. Different letters indicate significant differences within cover crop treatments $(p \leq 0.05)$.
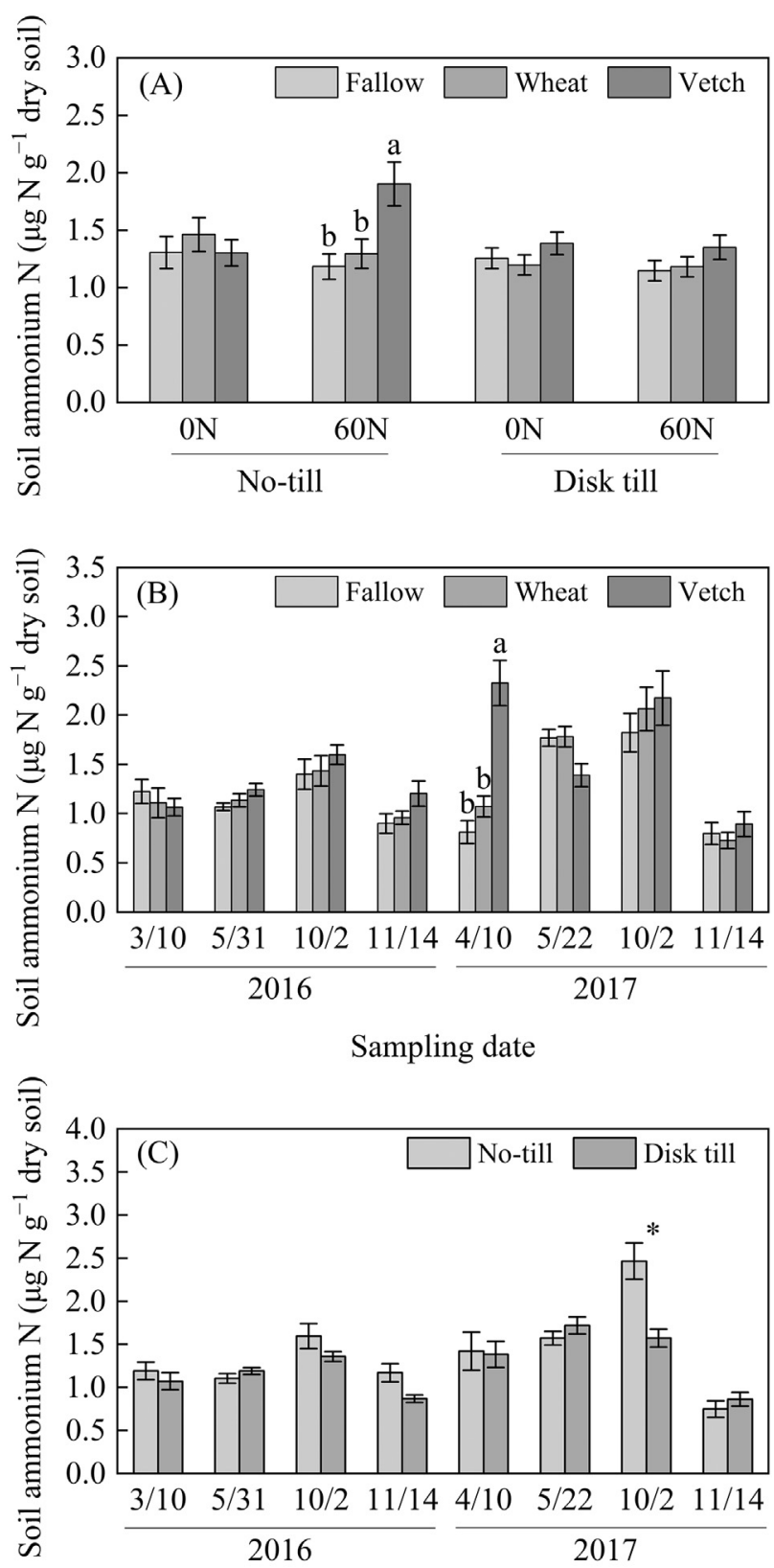

Sampling date

Fig. 4. Concentrations of soil ammonium N. (A) and (B): different letters indicate significant differences within cover crop treatments $(p \leq 0.05)$. (C): an asterisk denotes a significant difference within tillage treatments.

and no-till soils. Wheat cover crops increased PNM compared to fallow only in disked soils, with Fisher's LSD being significant $(p=0.0129)$ but Tukey's LSD not significant ( $p=0.1271$ ). Soil PNM in 2016 was higher than 2017 but only in disked soils in March (April) and November $(p=0.0040)$.

\subsection{Seasonal temperature and precipitation}

Monthly average air temperature and monthly cumulative precipitation differed throughout 2016-2017 (Fig. 7). October 2016 was relatively hotter and November 2016 and October 2017 were fairly dry compared to other months. The monthly average air temperature and monthly cumulative precipitation data were used in our structural equation modeling. 

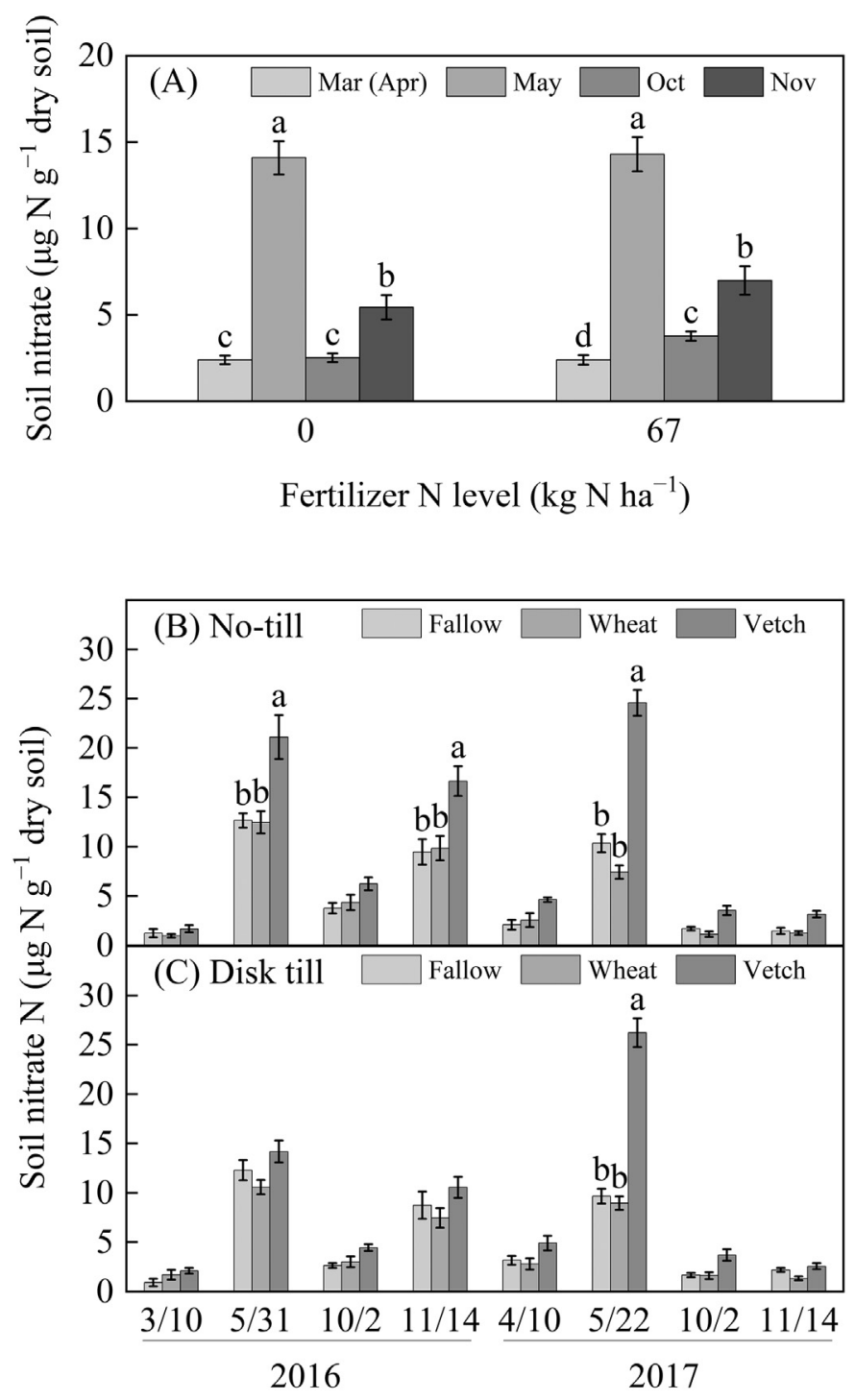

Sampling date

Fig. 5. Concentrations of soil nitrate N. (A): different letters indicate significant differences within sampling months $(p \leq 0.05)$. (B) and $(C)$ : different letters indicate significant differences within cover crop treatments.

\subsection{Structural equation model for effects of agricultural practices on soil $N$} concentrations

The goodness-of-fit indices suggested optimal fit of our measured data to the structural equation model $(\mathrm{CMIN} / \mathrm{DF}=1.04$, $\mathrm{GFI}=0.98, \mathrm{CFI}=1.00, \mathrm{RMSEA}=0.01$, Fig. 8 ). Total $\mathrm{N}$ concentration had a $R^{2}$ value of 0.49 . Fertilizer had direct effects on total $\mathrm{N}$ (effect size $=0.37$ ), $\delta^{15} \mathrm{~N}$ value (effect size $=0.29$ ), PNM (effect size $=0.17$ ), and $\mathrm{pH}$ (effect size $=-0.14$, Fig. 8). These pathways led to a positive total effect of fertilizer on total $\mathrm{N}$ (effect size $=$ 0.41 , Table 1 ). Vetch had direct effects on total $\mathrm{N}$ (effect size $=$ $0.31), \delta^{15} \mathrm{~N}$ value (effect size $=0.14$ ), PNM (effect size $=0.35$ ), EON (effect size $=0.17$ ), ammonium (effect size $=0.12$ ), and nitrate (effect size $=0.30$, Fig. 8 ). Overall, vetch had a positive total effect on total N (effect size $=0.43$, Table 1 ). Disk tillage had direct effects on total $\mathrm{N}$ (effect size $=-0.19$ ) and $\mathrm{pH}$ (effect size $=0.15$, Fig. 8). The total effect size of disk tillage on total $\mathrm{N}$ was -0.19 (Table 1).
3.6. Structural equation model for effects of temperature and precipitation on soil $N$ concentrations

The goodness-of-fit indices suggested optimal model fit (CMIN/ $\mathrm{DF}=1.45, \mathrm{GFI}=0.99, \mathrm{CFI}=1.00, \mathrm{RMSEA}=0.03$, Fig. 9). Total $\mathrm{N}$ concentration had a $R^{2}$ value of 0.24 . Monthly average air temperature had positive effects on MBN, EON, ammonium, and nitrate, monthly cumulative precipitation had positive effects on MBN, EON, and nitrate but a negative effect on total $\mathrm{N}$ (Fig. 9). The total effects of climatic factors on soil $\mathrm{N}$ concentrations were in Table 2.

To disaggregate the interaction effect of seasonal factors (temperature and precipitation) and agricultural practice, we tested this model under different agricultural practices (Supplementary Figs. 9-11). The effects of temperature and precipitation on MBN, ammonium, and nitrate were smaller under vetch than fallow (Table 3), and smaller under $67 \mathrm{~kg} \mathrm{~N}^{-1}$ fertilizer than zero-fertilizer (Supplementary Table 1). The effects of precipitation on MBN, EON, ammonium, and nitrate were smaller under no-till than disk tillage (Supplementary Table 2).

\section{Discussion}

Seasonal monitoring of soil $\mathrm{N}$ concentrations in this long-term continuous cotton system indicated various effects of agricultural management on soil $\mathrm{N}$ cycling and stabilization under climatic variability. Inorganic $\mathrm{N}$ fertilizer and vetch cover crop increased microbial transformation rates of soil $\mathrm{N}$, which can contribute to soil total $\mathrm{N}$. Vetch could also improve soil labile $\mathrm{N}$ concentrations as demonstrated by structural equation modeling (Fig. 8). Vetch, compared to fertilizer, had larger effects on improving soil $\mathrm{N}$ concentrations (Table 1). Wheat cover crops did not have any significant effects on soil $\mathrm{N}$ concentrations. Increased temperature and intensified precipitation increased soil $\mathrm{N}$ lability, and thus loss potential (Fig. 9). With fertilizer or vetch cover crop application, soil labile $\mathrm{N}$ concentrations tended to be less sensitive to climatic factors possibly due to faster microbial $\mathrm{N}$ transformation (Table 3 ). No-till increased soil total $\mathrm{N}$ and might reduce the effects of precipitation compared to disk tillage.

\subsection{Effects of long-term inorganic $N$ fertilization on soil total $N$}

Long-term application of inorganic $\mathrm{N}$ fertilizer increased soil total $\mathrm{N}$ (Fig. 1), suggesting a significant transfer of labile mineral $\mathrm{N}$ forms to more stable $\mathrm{N}$ in bulk soils. Structural equation modeling demonstrated four direct or indirect pathways for fertilizer to affect soil $\mathrm{N}$ cycling (Fig. 8). Specifically, fertilizer directly contributed to soil total $\mathrm{N}$ (Fig. 8). In addition, fertilizer $\mathrm{N}$ can be recovered in crop biomass (Poffenbarger et al., 2018) and returned to soil as aboveground litter, root litter, and root exudates (De Notaris et al., 2020). As plant residues decompose, a fraction of plant $\mathrm{N}$ derived from fertilizer can be sequestered in soil for longer term due to resistance to microbial decomposition, adsorption to mineral surfaces, and occlusion within aggregates (Bingham and Cotrufo, 2016). Fertilizer $\mathrm{N}$ can also be retained in soil as microbial residues. Structural equation modeling indicated that fertilizer could also increase soil total $\mathrm{N}$ through elevating soil $\delta^{15} \mathrm{~N}$ value and potential $\mathrm{N}$ mineralization (Fig. 8). Higher soil $\delta^{15} \mathrm{~N}$ value and potential $\mathrm{N}$ mineralization reflect isotope fractionation during faster microbial $\mathrm{N}$ transformation rates which enrich the ${ }^{15} \mathrm{~N}$ remaining in soils as lighter ${ }^{14} \mathrm{~N}$ is preferentially utilized during microbial processes, e.g., mineralization, nitrification, denitrification (Choi et al., 2017; Jones and Dalal, 2017). Our result is consistent with previous findings that fertilizer can stimulate microbial N transformation (Zou et al., 2019). During microbial transformation, microbes can produce stable soil organic matter (Chao et al., 2017; Kallenbach et al., 2016). This stable soil organic matter can support build-up of the $\mathrm{N}$ sequestered in soil for centuries to millennia (Bingham and Cotrufo, 2016; Chao et al., 2017). Additionally, fertilizer can reduce soil total $\mathrm{N}$ indirectly by decreasing soil 


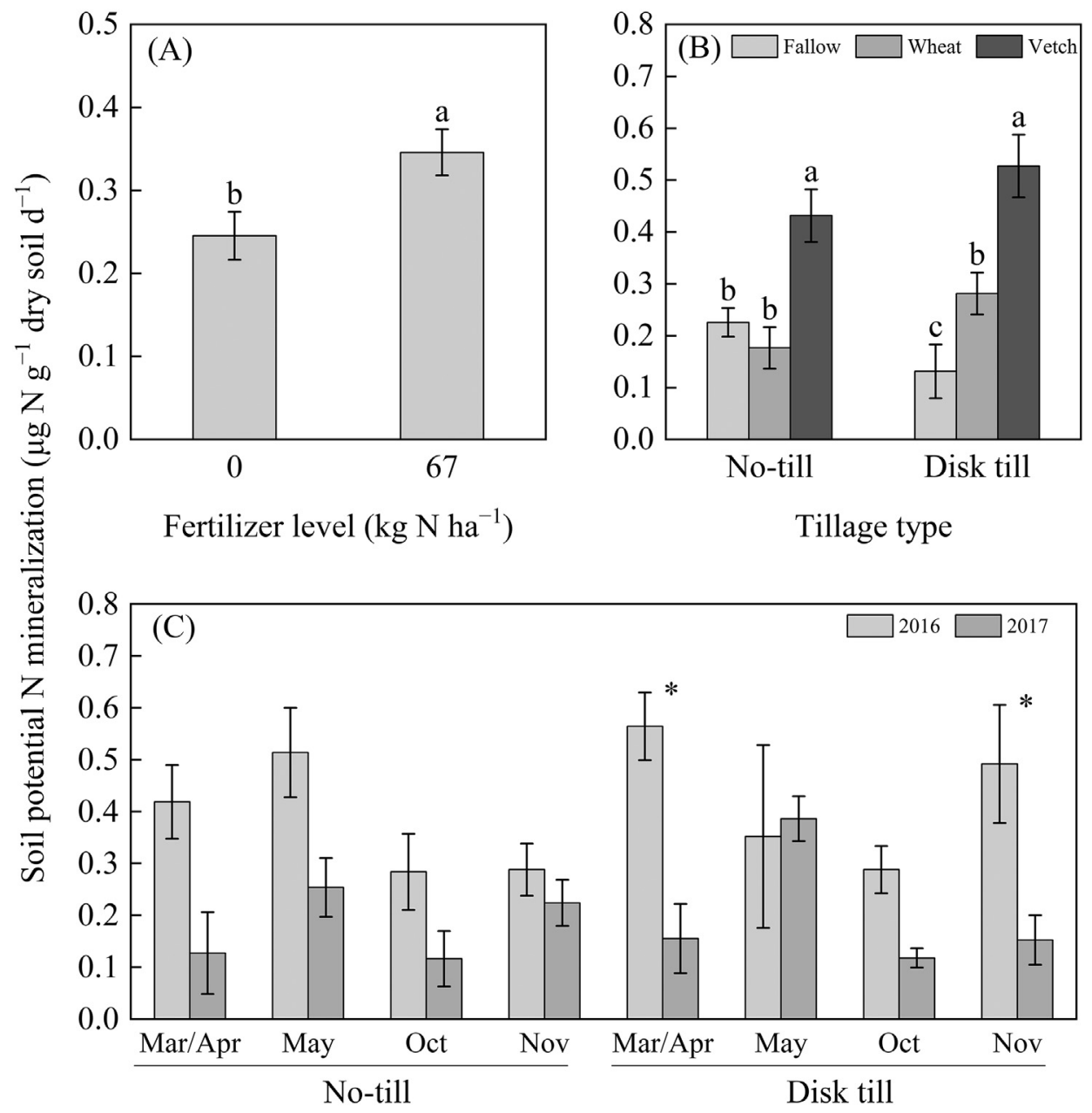

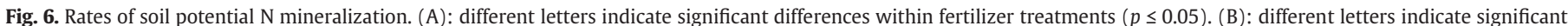
differences within cover crop treatments. (C): an asterisk denotes a significant difference within sampling years.

$\mathrm{pH}$, which would lower both soil $\delta^{15} \mathrm{~N}$ value and potential $\mathrm{N}$ mineralization (Fig. 8). The long-term acidification of soils associated with fertilizer inputs can alter microbial community structure and reduce the abundance and activity of microbes that are sensitive to $\mathrm{pH}$ (Jangid et al., 2008; Li et al., 2020; Song et al., 2016). This can reduce the $\mathrm{N}$ transformation and residue accumulation of these microbes and thus soil total N. Despite the minor negative effect, fertilizer had an overall positive effect on soil total $\mathrm{N}$, while vetch had a slightly larger effect on soil total $\mathrm{N}$ compared to fertilizer ( $0.43 \mathrm{vs}$. 0.41 , Table 1 ).

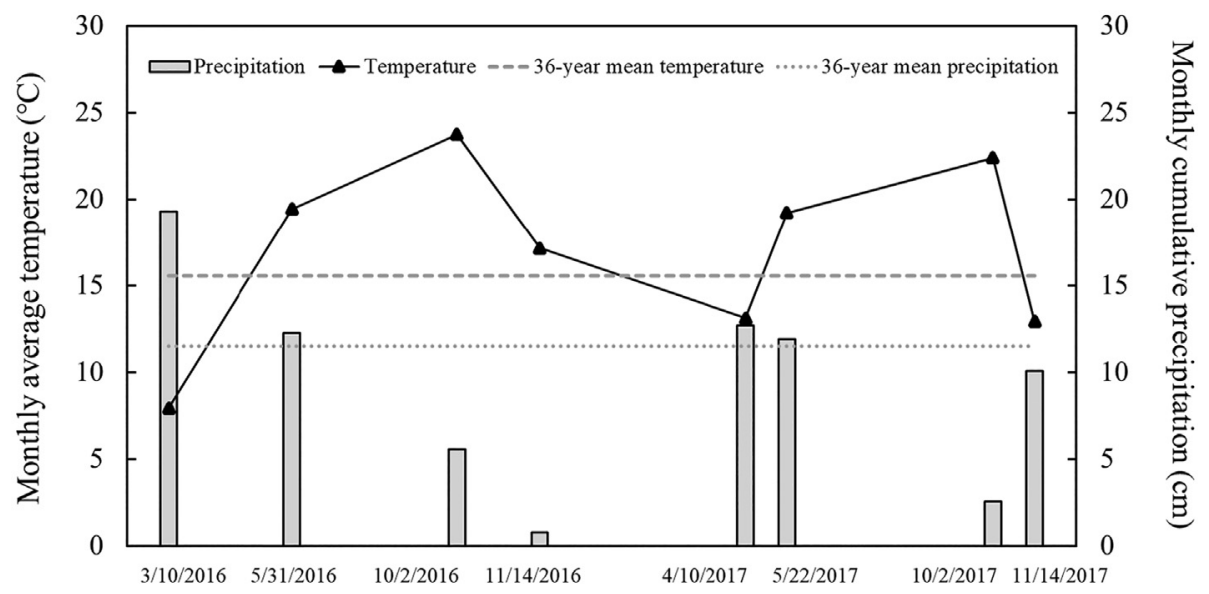

Sampling date

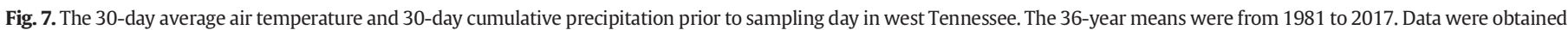
from Jackson Experiment Station via National Weather Service Forecast Office. 


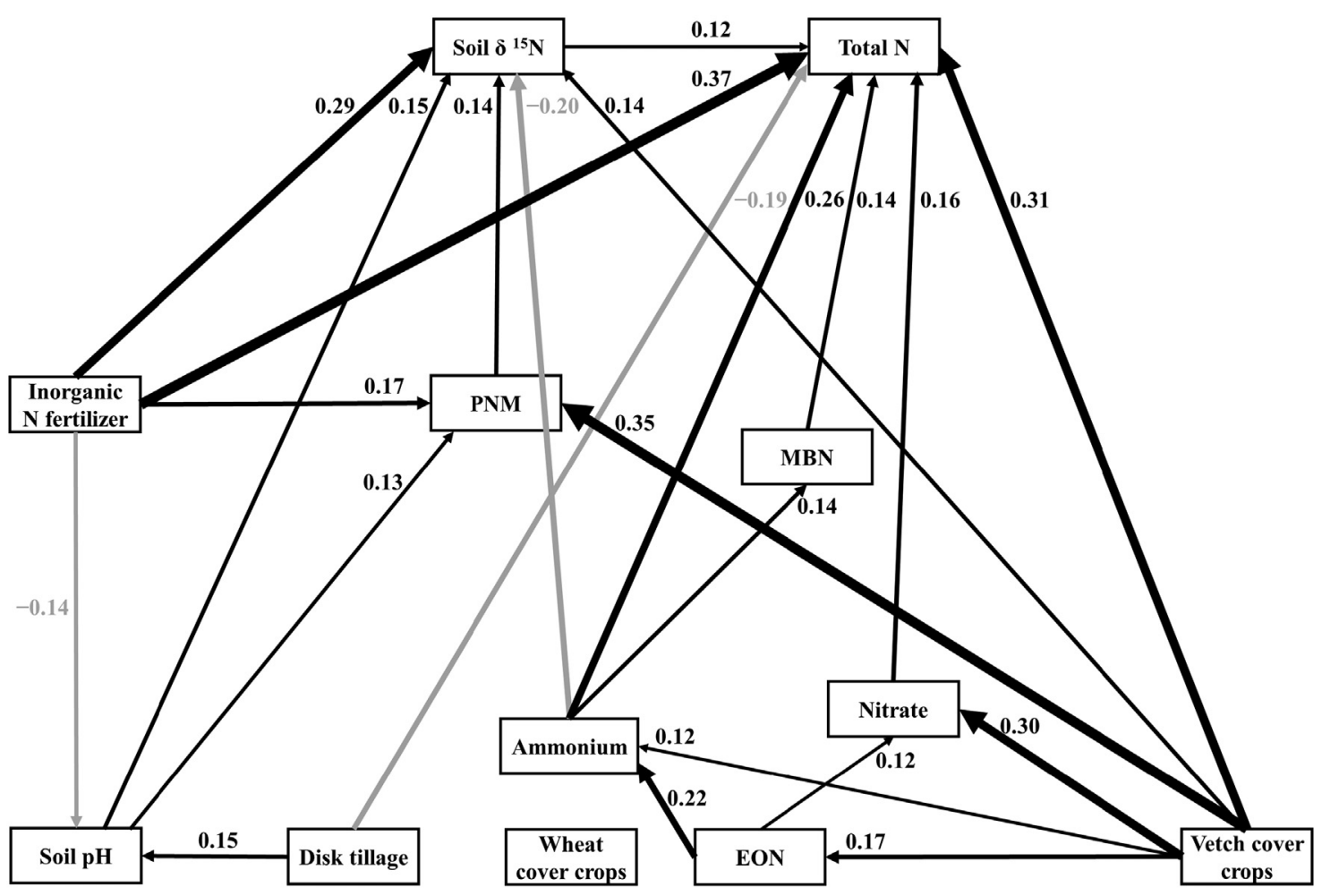

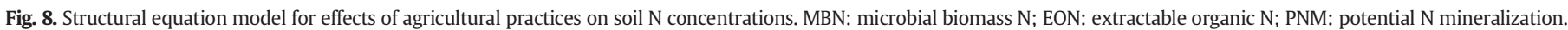

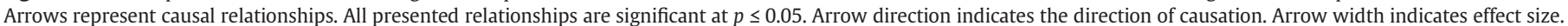

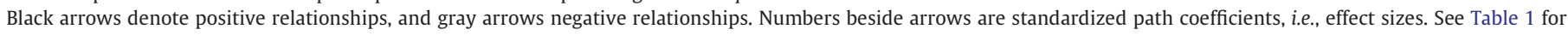
standardized total effects.

\subsection{Effects of long-term vetch cover cropping on soil $N$ concentrations}

Like fertilizer, vetch cover crop can improve soil total $\mathrm{N}$ through increasing $\mathrm{N}$ inputs and accelerating microbial $\mathrm{N}$ transformation (Fig. 8). The main $\mathrm{N}$ inputs from vetch is through both its biomass (i.e. aboveand below-ground litter) $\mathrm{N}$ contributions and also direct exudation of $\mathrm{N}$ resulting from biological $\mathrm{N}$-fixation in its roots (Fustec et al., 2010). Additionally, vetch had a larger direct effect on potential $\mathrm{N}$ mineralization than fertilizer ( 0.35 vs. 0.17 , Fig. 8). The $\mathrm{N}$ input from legume can increase microbial diversity and $\mathrm{N}$ mineralization compared to fertilizer (Berthrong et al., 2013), leading to larger amounts of microbially processed materials and therefore potential of sequestered $\mathrm{N}$ for long term (Cotrufo et al., 2013). Beyond that, vetch can improve soil labile $\mathrm{N}$ concentrations (i.e., extractable organic N, ammonium, nitrate; Fig. 8), likely resulting from the direct exudation of $\mathrm{N}$ from roots into the rhizosphere as well as the decomposition of vetch residues. Vetch residues release $\mathrm{N}$ slowly and therefore more synchronously with microbial demands

Table 1

Standardized total effects of conservation management on soil N concentrations.

\begin{tabular}{llcc}
\hline & Vetch cover crop & Inorganic N fertilizer & Disk tillage \\
\hline Total N & 0.43 & 0.41 & -0.19 \\
$\delta^{15} \mathrm{~N}$ & 0.16 & 0.29 & 0.02 \\
Soil pH & 0.00 & -0.14 & 0.15 \\
MBN & 0.02 & 0.00 & 0.00 \\
EON & 0.17 & 0.00 & 0.00 \\
Ammonium & 0.15 & 0.00 & 0.00 \\
Nitrate & 0.32 & 0.00 & 0.00 \\
PNM & 0.35 & 0.15 & 0.02 \\
\hline
\end{tabular}

MBN: microbial biomass N; EON: extractable organic N; PNM: potential N mineralization. All effects are significant at $p \leq 0.05$. See Fig. 8 for direct and indirect pathways. compared to fertilizer, leading to increases in microbial biomass $\mathrm{N}$. Vetch residues can provide more than $20 \mathrm{~kg} \mathrm{~N} \mathrm{ha}^{-1}$ for over 70 days after termination (Liebman et al., 2018). The increased extractable organic $\mathrm{N}$, ammonium, and microbial biomass $\mathrm{N}$ will benefit soil $\mathrm{N}$ retention, as well as $\mathrm{N}$ availability for the following cotton crops. The mineral $\mathrm{N}$ released from vetch decomposition can contribute to the $\mathrm{N}$ fertilizer effect of legume cover crops (De Notaris et al., 2020; Yang et al., 2020). Substituting fertilizer with vetch may decrease soil N losses, as systems that utilize both are likely to exceed crop requirements.

\subsection{Effects of long-term disk tillage on soil $N$ concentrations}

In contrast to vetch, disk tillage had an overall negative effect on soil total $\mathrm{N}$ ( $0.43 v$ s. -0.19 , Table 1$)$. The structural equation model (Fig. 8) showed two pathways of disk tillage affecting soil total $\mathrm{N}$ : (1) reducing soil total $\mathrm{N}$ by disrupting soil structure and breaking soil aggregates (Mei et al., 2018; Piazza et al., 2020); and (2) enhancing soil total N by increasing soil $\mathrm{pH}$, which improves soil conditions for microbial activity and increases soil $\delta^{15} \mathrm{~N}$ value and potential $\mathrm{N}$ mineralization (Fig. 8). Disk tillage increased soil pH from $6.05 \pm 0.06$ to $6.19 \pm 0.06$. Since lime was applied in this field site, when the soil was tilled, some of the residual lime was remixed in the surface soil and could keep soil pH slightly higher than no-till. In no-till soils, greater stratification of soil $\mathrm{pH}$ can be a result of no soil mixing. Plus, acidification caused by fertilizer application to the surface is usually most pronounced in nearsurface soils (0 to $7.6 \mathrm{~cm}$ ) (Reeves and Liebig, 2016), so disk tillage would likely decrease the acidification in surface soils compared to no-till (Ghimire et al., 2017). The less acidified soils can be favorable for microbial activity and lead to accumulation of microbial residues, contributing to soil total $\mathrm{N}$. This indirect positive effect of disk tillage on soil total $\mathrm{N}$ through $\mathrm{pH}$ is relatively minor and overshadowed by the direct negative effect of disk tillage on soil total $\mathrm{N}$ (0.003 vs. 


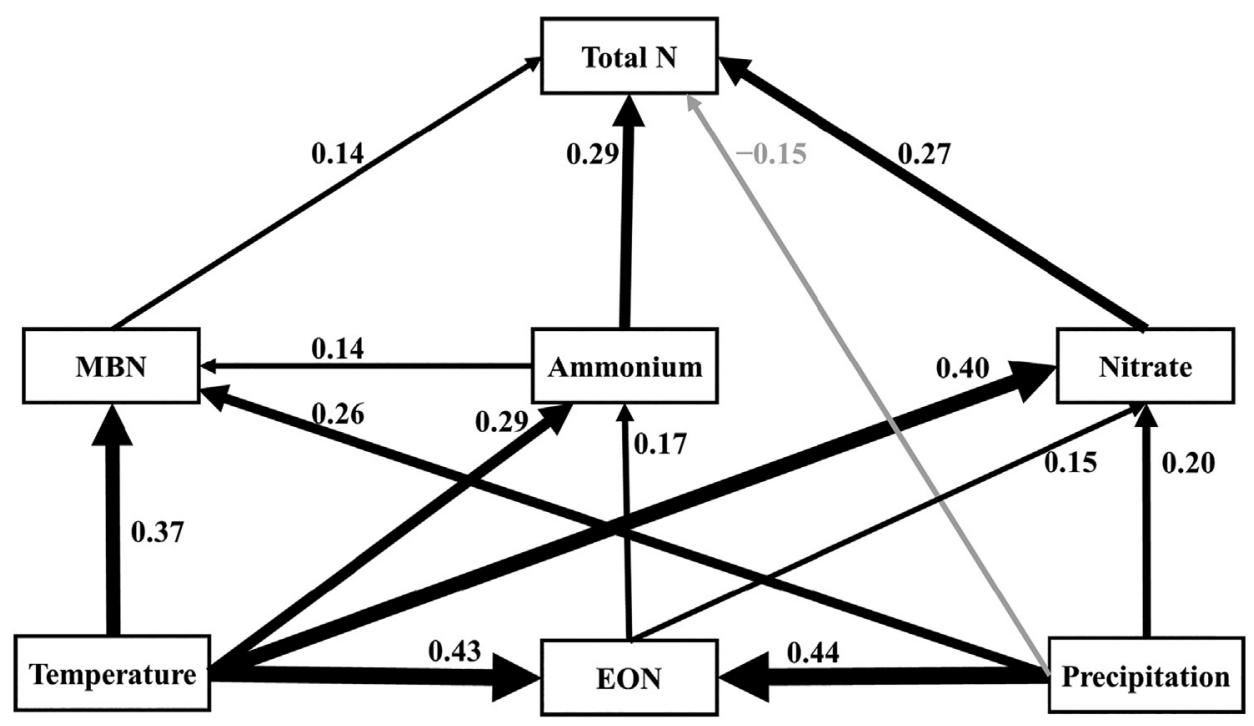

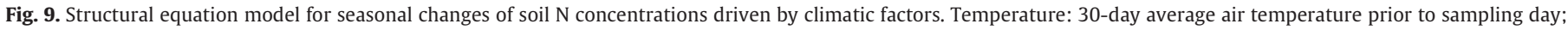

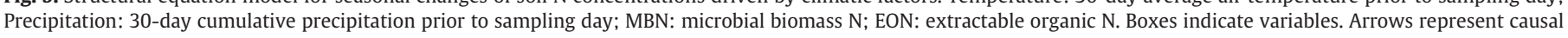

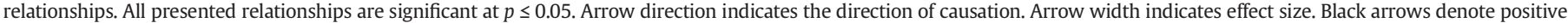
relationships, and gray arrows negative relationships. Numbers beside arrows are standardized path coefficients, i.e., effect sizes. See Table 2 for standardized total effects.

$-0.19)$. These two pathways result in an overall negative effect of disk tillage on soil total $\mathrm{N}$.

\subsection{Interaction effects of conservation management and temperature and precipitation on soil $N$ concentrations}

Our results from structural equation modeling imply that increased temperature and intensified precipitation might potentially destabilize soil $\mathrm{N}$ and therefore increase soil $\mathrm{N}$ loss. The structural equation model showed that temperature can increase soil microbial biomass N (Fig. 9). Microbial biomass is the main driver of soil N turnover (Li et al., 2019b). Thus, increased temperature may accelerate $\mathrm{N}$ mineralization and nitrification (Miller and Geisseler, 2018; Taylor et al., 2019; Thangarajan et al., 2015), through which extractable organic N, ammonium, and nitrate are increased (Fig. 9). Likewise, increased precipitation can stimulate soil microbial biomass and activity, e.g., heterotrophic respiration and N mineralization (Chen et al., 2017; Hess et al., 2020; Song et al., 2020), during which soil total $\mathrm{N}$ can be consumed and extractable organic $\mathrm{N}$ and nitrate are increased (Fig. 9). These results indicate that increased temperature and intensified precipitation might increase the lability of soil N. Further, the labile $\mathrm{N}$ can be leached through soil profiles upon intensified rainfalls (Hess et al., 2020), exacerbating soil losses from cropping systems. However, temperature and precipitation only explained $24 \%$ of the seasonal changes in soil total $\mathrm{N}$. Other concomitant factors can control soil $\mathrm{N}$ loss with temperature and precipitation. Considering the interaction effects of conservation management and season on soil $\mathrm{N}$ concentrations (Figs. $1-5$ ), the seasonal variations in soil $\mathrm{N}$ loss might be minimized by adjusting agricultural management. Vetch

Table 2

Standardized total effects of temperature and precipitation on soil N concentrations.

\begin{tabular}{llc}
\hline & Temperature & Precipitation \\
\hline Total N & 0.28 & -0.02 \\
MBN & 0.37 & 0.26 \\
EON & 0.43 & 0.44 \\
Ammonium & 0.36 & 0.07 \\
Nitrate & 0.46 & 0.26 \\
\hline
\end{tabular}

Temperature: 30-day average air temperature prior to sampling day; Precipitation: 30 day cumulative precipitation prior to sampling day; MBN: microbial biomass N; EON: extractable organic N. All effects are significant at $p \leq 0.05$. See Fig. 9 for direct and indirect pathways. can reduce the effects of temperature and precipitation on microbial biomass $\mathrm{N}$, ammonium, and nitrate compared to fallow (Table 3 ) probably due to faster $\mathrm{N}$ transformation under vetch. Fertilizer application, compared to zero-fertilizer, can have the similar effects as vetch (Supplementary Table 2) since fertilizer can also accelerate $\mathrm{N}$ transformation. No-till, compared to disk tillage, can decrease the effects of precipitation on microbial biomass $\mathrm{N}$, extractable organic $\mathrm{N}$, ammonium, and nitrate (Supplementary Table 3). No-till can increase soil penetration resistance and aggregate stability compared to tillage (Nouri et al., 2019; Singh et al., 2020), which might reduce the effects of intensified precipitation.

\section{Conclusions}

Our study demonstrated the mechanisms of how conservation management improves agroecosystem resilience by mitigating the effects of increased temperature and intensified precipitation on soil N. Our results showed that both inorganic $\mathrm{N}$ fertilizer and vetch cover crop can accelerate microbial transformation of soil $\mathrm{N}$ and facilitate accumulation of stable soil $\mathrm{N}$, and therefore enhance soil total $\mathrm{N}$ concentration, with vetch having a slightly larger effect than fertilizer. Vetch also improved soil labile $\mathrm{N}$ concentrations and thus soil $\mathrm{N}$ availability for crops and microbes. We did not observe significant effects of fertilizer on labile $\mathrm{N}$ concentrations possibly because these effects were short-lived. No-till can improve soil total $\mathrm{N}$ due to reduced disturbance compared to disk tillage. Increased temperature and intensified precipitation might potentially increase the lability of soil N, leading to soil N losses. Vetch, fertilizer, and no-till may reduce some of the effects of temperature and precipitation on soil labile $\mathrm{N}$ concentrations. The potential of soil $\mathrm{N}$ loss due to increased temperature and intensified precipitation might be mitigated through appropriate agricultural management. Conservation agricultural management can be an effective approach to improving agroecosystem function and productivity.

\section{CRediT authorship contribution statement}

Lidong Li: Conceptualization, Formal analysis, Investigation, Writing original draft. Julie Konkel: Investigation, Data curation, Resources, Writing - review \& editing. Virginia L. Jin: Investigation, Funding acquisition, Writing - review \& editing. Sean M. Schaeffer: Conceptualization, 
Table 3

Standardized total effects of temperature and precipitation on soil N concentrations under different cover crops.

\begin{tabular}{|c|c|c|c|c|c|c|}
\hline & \multirow{2}{*}{$\frac{\text { Fallow }}{\text { Temperature }}$} & \multirow[b]{2}{*}{ Precipitation } & \multicolumn{2}{|c|}{ Wheat cover crops } & \multicolumn{2}{|c|}{ Vetch cover crops } \\
\hline & & & Temperature & Precipitation & Temperature & Precipitation \\
\hline Total N & 0.17 & 0.05 & 0.22 & 0.08 & 0.14 & -0.26 \\
\hline MBN & 0.47 & 0.37 & 0.23 & 0.00 & 0.31 & 0.28 \\
\hline EON & 0.34 & 0.38 & 0.46 & 0.44 & 0.52 & 0.54 \\
\hline Ammonium & 0.44 & 0.13 & 0.51 & 0.15 & 0.21 & 0.00 \\
\hline Nitrate & 0.47 & 0.22 & 0.45 & 0.20 & 0.45 & 0.18 \\
\hline
\end{tabular}

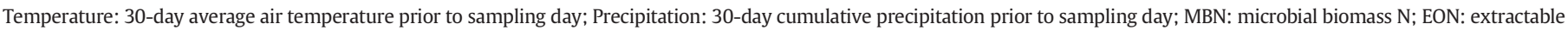
organic N. All effects are significant at $p \leq 0.05$. See Supplementary Fig. 9 for direct and indirect pathways.

Writing - original draft, Supervision, Project administration, Funding acquisition.

\section{Declaration of competing interest}

The authors declare that they have no known competing financial interests or personal relationships that could have appeared to influence the work reported in this paper.

\section{Acknowledgements}

This work is dedicated to the memory of Dr. Donald Tyler (1950-2017) for his work establishing the experimental plots in 1981. We wish to acknowledge the West Tennessee Research and Education Center for access to the field site and the National Weather Service Forecast Office for access to the climate data. This work was supported by National Institute of Food and Agriculture (USDA-NIFA 2015-67019-23604 and USDA-NIFA 00529W3118) funding to Dr. Sean Schaeffer.

\section{Appendix A. Supplementary data}

Supplementary data to this article can be found online at https://doi. org/10.1016/j.scitotenv.2021.146457.

\section{References}

Abdalla, M., Hastings, A., Cheng, K., Yue, O., Chadwick, D., Espenberg, M., et al., 2019. A critical review of the impacts of cover crops on nitrogen leaching, net greenhouse gas balance and crop productivity. Glob. Chang. Biol. https://doi.org/10.1111/ gcb.14644.

Bentler, P.M., 1990. Comparative fit indexes in structural models. Psychol. Bull. 107, 238-246. https://doi.org/10.1037/0033-2909.107.2.238.

Berthrong, S.T., Buckley, D.H., Drinkwater, L.E., 2013. Agricultural management and labile carbon additions affect soil microbial community structure and interact with carbon and nitrogen cycling. Microb. Ecol. 66, 158-170. https://doi.org/10.1007/s00248-0130225-0.

Bingham, A.H., Cotrufo, M.F., 2016. Organic nitrogen storage in mineral soil: implications for policy and management. Sci. Total Environ. 551, 116-126. https://doi.org/ 10.1016/j.scitotenv.2016.02.020.

Browne MW, Cudeck R. Alternative ways of assessing model fit In: Bollen KA \& Long JS. Testing structural equation models. Beverly Hills, CA: Sage 1993: 111-135.

Byrne BM. Structural equation modeling with AMOS: Basic concepts, applications, and programming: New York: Routledge, 2013.

Carmines EG, Mclver JP. An introduction to the analysis of models with unobserved variables. Political Methodology 1983: 51-102. jstor.org/stable/25791175.

Chao, L., Joshua, P.S., Julie, D.J., 2017. The importance of anabolism in microbial control over soil carbon storage. Nat. Microbiol. 2, 17105. https://doi.org/10.1038/ nmicrobiol.2017.105.

Chatterjee, A., Clay, D.E., 2016. Cover crops impacts on nitrogen scavenging, nitrous oxide emissions, nitrogen fertilizer replacement, erosion, and soil health. Soil Fertility Management in Agroecosystems, 76-89 https://doi.org/10.2134/soilfertility.2016.0012.

Chen, J., Xiao, G., Kuzyakov, Y., Jenerette, G.D., Ma, Y., Liu, W., et al., 2017. Soil nitrogen transformation responses to seasonal precipitation changes are regulated by changes in functional microbial abundance in a subtropical forest. Biogeosciences 14, 2513-2525. https://doi.org/10.5194/bg-14-2513-2017.

Choi, W.-J., Kwak, J.-H., Lim, S.-S., Park, H.-J., Chang, S.X., Lee, S.-M., et al., 2017. Synthetic fertilizer and livestock manure differently affect $\delta 15 \mathrm{~N}$ in the agricultural landscape: a review. Agric. Ecosyst. Environ. 237, 1-15. https://doi.org/10.1016/j.agee.2016.12.020.

Comeau, L.-P., Hergoualc'h, K., Hartill, J., Smith, J., Verchot, L.V., Peak, D., et al., 2016. How do the heterotrophic and the total soil respiration of an oil palm plantation on peat respond to nitrogen fertilizer application? Geoderma 268, 41-51. https://oi.org/ 10.1016/j.geoderma.2016.01.016.

Congreves, K., Dutta, B., Grant, B., Smith, W., Desjardins, R., Wagner-Riddle, C., 2016. How does climate variability influence nitrogen loss in temperate agroecosystems under contrasting management systems? Agriculture. Ecosystems \& Environment 227, 33-41. https://doi.org/10.1016/j.agee.2016.04.025.

Cotrufo, M.F., Wallenstein, M.D., Boot, C.M., Denef, K., Paul, E., 2013. The Microbial Efficiency-Matrix Stabilization (MEMS) framework integrates plant litter decomposition with soil organic matter stabilization: do labile plant inputs form stable soil organic matter? Glob. Chang. Biol. 19, 988-995. https://doi.org/10.1111/gcb.12113.

De Notaris, C., Olesen, J.E., Sørensen, P., Rasmussen, J., 2020. Input and mineralization of carbon and nitrogen in soil from legume-based cover crops. Nutr. Cycl. Agroecosyst. 116, 1-18. https://doi.org/10.1007/s10705-019-10026-z.

Doane, T.A., Horwáth, W.R., 2003. Spectrophotometric determination of nitrate with a single reagent. Anal. Lett. 36, 2713-2722. https://doi.org/10.1081/AL-120024647.

Fang, C., J-s, Ye, Gong, Y., Pei, J., Yuan, Z., Xie, C., et al., 2017. Seasonal responses of soil respiration to warming and nitrogen addition in a semi-arid alfalfa-pasture of the Loess Plateau, China. Sci. Total Environ. 590, 729-738. https://doi.org/10.1016/j. scitotenv.2017.03.034.

Fierer, N., Schimel, J.P., 2002. Effects of drying-rewetting frequency on soil carbon and nitrogen transformations. Soil Biol. Biochem. 34, 777-787. https://doi.org/10.1016/ S0038-0717(02)00007-X

Fierer, N., Schimel, J.P., Holden, P.A., 2003. Influence of drying-rewetting frequency on soil bacterial community structure. Microbial Ecol. 45, 63-71. https://doi.org/10.1007/ s00248-002-1007-2.

Fustec, J., Lesuffleur, F., Mahieu, S., Cliquet, J.-B., 2010. Nitrogen rhizodeposition of legumes. A review. Agronomy for Sustainable Development 30, 57-66. https://doi. org/10.1051/agro/2009003.

Ghimire, R., Machado, S., Bista, P., 2017. Soil pH, soil organic matter, and crop yields in winter wheat-summer fallow systems. Agron. J. 109, 706-717. https://doi.org/ 10.2134/agronj2016.08.0462.

Graham, S.L., Hunt, J.E., Millard, P., McSeveny, T., Tylianakis, J.M., Whitehead, D., 2014. Effects of soil warming and nitrogen addition on soil respiration in a New Zealand tussock grassland. PLoS One 9, e91204. https://doi.org/10.1371/journal.pone.0091204.

Greaver, T., Clark, C., Compton, J., Vallano, D., Talhelm, A., Weaver, C., et al., 2016. Key ecological responses to nitrogen are altered by climate change. Nat. Clim. Chang. 6 , 836-843. https://doi.org/10.1038/NCLIMATE3088.

Hess LJ, Hinckley E-LS, Robertson GP, Matson PA. Rainfall intensification increases nitrate leaching from tilled but not no-till cropping systems in the US Midwest. Agriculture, Ecosystems \& Environment 2020; 290: 106747. https://doi.org/ 10.1016/j.agee.2019.106747.

Jangid, K., Williams, M.A., Franzluebbers, A.J., Sanderlin, J.S., Reeves, J.H., Jenkins, M.B., et al., 2008. Relative impacts of land-use, management intensity and fertilization upon soil microbial community structure in agricultural systems. Soil Biol. Biochem. 40, 2843-2853. https://doi.org/10.1016/j.soilbio.2008.07.030.

Jones, A.R., Dalal, R.C., 2017. Enrichment of natural 15N abundance during soil N losses under 20 years of continuous cereal cropping. Sci. Total Environ. 574, 282-287. https://doi.org/10.1016/j.scitotenv.2016.08.192.

Kallenbach, C.M., Frey, S.D., Grandy, A.S., 2016. Direct evidence for microbial-derived soil organic matter formation and its ecophysiological controls. Nat. Commun. 7, 13630. https://doi.org/10.1038/ncomms13630.

Kumar, U., Nayak, A.K., Shahid, M., Gupta, V.V., Panneerselvam, P., Mohanty, S., et al., 2018. Continuous application of inorganic and organic fertilizers over 47 years in paddy soil alters the bacterial community structure and its influence on rice production. Agric. Ecosyst. Environ. 262, 65-75. https://doi.org/10.1016/j.agee.2018.04.016.

Li, L., Wilson, C.B., He, H., Zhang, X., Zhou, F., Schaeffer, S.M., 2019a. Physical, biochemical, and microbial controls on amino sugar accumulation in soils under long-term cover cropping and no-tillage farming. Soil Biol. Biochem. 135, 369-378. https://doi.org/ 10.1016/j.soilbio.2019.05.017.

Li, Z., Tian, D., Wang, B., Wang, J., Wang, S., Chen, H.Y., et al., 2019b. Microbes drive global soil nitrogen mineralization and availability. Glob. Chang. Biol. 25, 1078-1088. https://doi.org/10.1111/gcb.14557.

Li, Y., Tremblay, J., Bainard, L.D., Cade-Menun, B., Hamel, C., 2020. Long-term effects of nitrogen and phosphorus fertilization on soil microbial community structure and function under continuous wheat production. Environ. Microbiol. 22, 1066-1088. https:// doi.org/10.1111/1462-2920.14824.

Liebman, A.M., Grossman, J., Brown, M., Wells, M.S., Reberg-Horton, S., Shi, W., 2018. Legume cover crops and tillage impact nitrogen dynamics in organic corn production. Agron. J. 110, 1046-1057. https://doi.org/10.2134/agronj2017.08.0474. 
Lu, M., Yang, Y., Luo, Y., Fang, C., Zhou, X., Chen, J., et al., 2011. Responses of ecosystem nitrogen cycle to nitrogen addition: a meta-analysis. New Phytol. 189, 1040-1050. https://doi.org/10.1111/j.1469-8137.2010.03563.x.

Martínez, J.M., Galantini, J.A., Duval, M.E., López, F.M., 2017. Tillage effects on labile pools of soil organic nitrogen in a semi-humid climate of Argentina: a long-term field study. Soil Tillage Res. 169, 71-80. https://doi.org/10.1016/j.still.2017.02.001.

Matthews, A., Armstrong, A., Leeds-Harrison, P., Harris, G., Catt, J., 2000. Development and testing of a model for predicting tillage effects on nitrate leaching from cracked clay soils. Soil Tillage Res. 53, 245-254. https://doi.org/10.1016/S0167-1987(99)00109-9.

Mazzoncini, M., Antichi, D., Di Bene, C., Risaliti, R., Petri, M., Bonari, E., 2016. Soil carbon and nitrogen changes after 28 years of no-tillage management under Mediterranean conditions. Eur. J. Agron. 77, 156-165. https://doi.org/10.1016/j.eja.2016.02.011.

Mbuthia, L.W., Acosta-Martínez, V., DeBruyn, J., Schaeffer, S., Tyler, D., Odoi, E., et al., 2015. Long term tillage, cover crop, and fertilization effects on microbial community structure, activity: implications for soil quality. Soil Biol. Biochem. 89, 24-34. https://doi. org/10.1016/j.soilbio.2015.06.016.

Mei, K., Wang, Z., Huang, H., Zhang, C., Shang, X., Dahlgren, R.A., et al., 2018. Stimulation of N2O emission by conservation tillage management in agricultural lands: a metaanalysis. Soil Tillage Res. 182, 86-93. https://doi.org/10.1016/j.still.2018.05.006.

Miller, K.S., Geisseler, D., 2018. Temperature sensitivity of nitrogen mineralization in agricultural soils. Biol. Fertil. Soils 54, 853-860. https://doi.org/10.1007/s00374-0181309-2.

Nouri, A., Lee, J., Yin, X., Tyler, D.D., Saxton, A.M., 2019. Thirty-four years of no-tillage and cover crops improve soil quality and increase cotton yield in Alfisols, southeastern USA. Geoderma 337, 998-1008. https://doi.org/10.1016/j.geoderma.2018.10.016.

Nouri A, Lee J, Yoder DC, Jagadamma S, Walker FR, Yin X, et al. Management duration controls the synergistic effect of tillage, cover crop, and nitrogen rate on cotton yield and yield stability. Agriculture, Ecosystems \& Environment 2020; 301: 107007. https:// doi.org/10.1016/j.agee.2020.107007.

Ozlu, E., Kumar, S., 2018. Response of surface GHG fluxes to long-term manure and inorganic fertilizer application in corn and soybean rotation. Sci. Total Environ. 626, 817-825. https://doi.org/10.1016/j.scitotenv.2018.01.120.

Pareja-Sánchez E, Cantero-Martínez C, Álvaro-Fuentes J, Plaza-Bonilla D. Impact of tillage and $\mathrm{N}$ fertilization rate on soil N2O emissions in irrigated maize in a Mediterranean agroecosystem. Agriculture, Ecosystems \& Environment 2020; 287: 106687. https:// doi.org/10.1016/j.agee.2019.106687.

Piazza, G., Pellegrino, E., Moscatelli, M.C., Ercoli, L., 2020. Long-term conservation tillage and nitrogen fertilization effects on soil aggregate distribution, nutrient stocks and enzymatic activities in bulk soil and occluded microaggregates. Soil Tillage Res. 196, 104482. https://doi.org/10.1016/j.still.2019.104482.

Poffenbarger, H.J., Sawyer, J.E., Barker, D.W., Olk, D.C., Six, J., Castellano, M.J., 2018. Legacy effects of long-term nitrogen fertilizer application on the fate of nitrogen fertilizer inputs in continuous maize. Agric. Ecosyst. Environ. 265, 544-555. https://doi.org/ 10.1016/j.agee.2018.07.005.

Reeves, J.L., Liebig, M.A., 2016. Depth matters: soil pH and dilution effects in the northern Great Plains. Soil Sci. Soc. Am. J. 80, 1424-1427. https://doi.org/ 10.2136/sssaj2016.02.0036n.

Rhine, E., Mulvaney, R., Pratt, E., Sims, G., 1998. Improving the Berthelot reaction for determining ammonium in soil extracts and water. Soil Sci. Soc. Am. J. 62, 473-480. https://doi.org/10.2136/sssaj1998.03615995006200020026x.

Risch, A.C., Zimmermann, S., Moser, B., Schütz, M., Hagedorn, F., Firn, J., et al., 2020. Global impacts of fertilization and herbivore removal on soil net nitrogen mineralization are modulated by local climate and soil properties. Glob. Chang. Biol. https://doi.org/ 10.1111/gcb.15308.

Shelton, R.E., Jacobsen, K.L., McCulley, R.L., 2018. Cover crops and fertilization alter nitrogen loss in organic and conventional conservation agriculture systems. Front. Plant Sci. 8, 2260. https://doi.org/10.3389/fpls.2017.02260.
Sievers, T., Cook, R.L., 2018. Aboveground and root decomposition of cereal rye and hairy vetch cover crops. Soil Sci. Soc. Am. J. 82, 147-155. https://doi.org/ 10.2136/sssaj2017.05.0139.

Šimek, M., Hopkins, D., Kalčík, J., Picek, T., Šantrůčková, H., Staňa, J., et al., 1999. Biological and chemical properties of arable soils affected by long-term organic and inorganic fertilizer applications. Biol. Fertil. Soils 29, 300-308. https://doi.org/10.1007/s003740050556.

Singh, S., Nouri, A., Singh, S., Anapalli, S., Lee, J., Arelli, P., et al., 2020. Soil organic carbon and aggregation in response to thirty-nine years of tillage management in the southeastern US. Soil Tillage Res. 197, 104523. https://doi.org/10.1016/j. still.2019.104523.

Song, H., Che, Z., Cao, W., Huang, T., Wang, J., Dong, Z., 2016. Changing roles of ammoniaoxidizing bacteria and archaea in a continuously acidifying soil caused by overfertilization with nitrogen. Environ. Sci. Pollut. Res. 23, 11964-11974. https://doi. org/10.1007/s11356-016-6396-8.

Song, H., Yan, T., Wang, J., Sun, Z., 2020. Precipitation variability drives the reduction of total soil respiration and heterotrophic respiration in response to nitrogen addition in a temperate forest plantation. Biol. Fertil. Soils 56, 273-279. https://doi.org/ 10.1007/s00374-019-01417-z.

Tanaka, J.S., Huba, G.J., 1985. A fit index for covariance structure models under arbitrary GLS estimation. Br. J. Math. Stat. Psychol. 38, 197-201. https://doi.org/10.1111/ j.2044-8317.1985.tb00834.x.

Taylor, A.E., Myrold, D.D., Bottomley, P.J., 2019. Temperature affects the kinetics of nitrite oxidation and nitrification coupling in four agricultural soils. Soil Biol. Biochem. 136, 107523. https://doi.org/10.1016/j.soilbio.2019.107523.

Thangarajan, R., Bolan, N.S., Naidu, R., Surapaneni, A., 2015. Effects of temperature and amendments on nitrogen mineralization in selected Australian soils. Environ. Sci. Pollut. Res. 22, 8843-8854. https://doi.org/10.1007/s11356-013-2191-y.

Treseder, K.K., 2008. Nitrogen additions and microbial biomass: a meta-analysis of ecosystem studies. Ecol. Lett. 11, 1111-1120. https://doi.org/10.1111/j.1461-0248.2008.01230.x.

Villamil, M.B., Little, J., Nafziger, E.D., 2015. Corn residue, tillage, and nitrogen rate effects on soil properties. Soil Tillage Res. 151, 61-66. https://doi.org/10.1016/j.still.2015.03.005.

Vogeler, I., Hansen, E.M., Thomsen, I.K., Østergaard, H.S., 2019. Legumes in catch crop mixtures: effects on nitrogen retention and availability, and leaching losses. J. Environ. Manag. 239, 324-332. https://doi.org/10.1016/j.jenvman.2019.03.077.

Wang, J., Zou, J., 2020. No-till increases soil denitrification via its positive effects on the activity and abundance of the denitrifying community. Soil Biol. Biochem. 107706. https://doi.org/10.1016/j.soilbio.2020.107706.

Wang, M., Pendall, E., Fang, C., Li, B., Nie, M., 2018. A global perspective on agroecosystem nitrogen cycles after returning crop residue. Agric. Ecosyst. Environ. 266, 49-54 https://doi.org/10.1016/j.agee.2018.07.019.

Wurtsbaugh, W.A., Paerl, H.W., Dodds, W.K., 2019. Nutrients, eutrophication and harmful algal blooms along the freshwater to marine continuum. Wiley Interdiscip. Rev. Water 6, e1373. https://doi.org/10.1002/wat2.1373.

Xiao, S., Ye, Y., Xiao, D., Chen, W., Zhang, W., Wang, K., 2019. Effects of tillage on soil N availability, aggregate size, and microbial biomass in a subtropical karst region. Soil Tillage Res. 192, 187-195. https://doi.org/10.1016/j.still.2019.05.006.

Yang, X., Drury, C.F., Reynolds, W., Phillips, L., 2020. Nitrogen release from shoots and roots of crimson clover, hairy vetch, and red clover. Can. J. Soil Sci. 100, 1-10. https://doi.org/10.1139/cjss-2019-0164.

Yu, C., Huang, X., Chen, H., Godfray, H.C.J., Wright, J.S., Hall, J.W., et al., 2019. Managing nitrogen to restore water quality in China. Nature 567, 516-520. https://doi.org/ 10.1038/s41586-019-1001-1.

Zou, C., Grove, J.H., Pearce, R.C., Coyne, M.S., Ren, K., 2019. What happens to in situ net soil nitrogen mineralization when nitrogen fertility changes? J. Plant Nutr. Soil Sci. 182, 296-306. https://doi.org/10.1002/jpln.201800551. 